Pregledni članak UDK 172.1:316.75(045)

doi: $10.21464 / \mathrm{fi} 39208$

Primljeno: 11. 4. 2018.

\title{
Erik Brezovec
}

Sveučilište u Zagrebu, Fakultet hrvatskih studija, Borongajska cesta 83d, HR-10000 Zagreb ebrezovec@hrstud.hr

\section{Fenomenologija odnosa nacionalnoga i kulturnoga identiteta u hrvatskom društvu}

\begin{abstract}
Sažetak
Cilj je rada analizirati fenomenologiju međuodnosa nacionalnoga $i$ kulturnoga identiteta $u$ hrvatskom i prikazati načine na koje ukotvljenost nacionalnog $i$ kulturnog identiteta u hrvatskom društvu generira percepciju pojedinca prema individualnom izričaju hrvatstva. Da bi se uopće moglo govoriti o ovom procesu bitno je definirati odnos kulturnoga i nacionalnoga identiteta u Republici Hrvatskoj. Taj odnos karakterizira dualnost utjecaja. Kulturni identitet bitna je sastavnica izgradnje nacionalnoga, koji određuje smjer kulturalne dinamike. Fenomenološka razina teorijske analize u fokus stavlja internalizaciju identitetskih sastavnica. Kako je svijest uvijek intencionalna, odnosno intendira predmet, valja proučiti načine shvaćanja izgradnje individualnog identiteta kroz zalihe koje se kolektivno pružaju. Takva vrsta konstrukcije, odnosno internalizacija kolektivnih pretpostavki, pretpostavlja relativnu neovisnost aktera u konstrukciji vlastite zbilje - pojedinac je slobodan formirati značenje, ali to značenje stvoreno je unutar određenoga konteksta i okvira. Taj kontekst na sebi svojstven način stvara esenciju znanja danu na raspolaganje. Osnovni problem sa znanjem nacionalnog $i$ kulturnog identiteta jest taj da je to znanje omogućeno u dvije dominantne varijante. Pojedinac svoj identitet konstruira kroz varijantu zalihe znanja, dominantnu (ili dostupnu) kroz njegov život. Takav proces ostvarenja osobe disperzira nacionalni identitet. $U$ fenomenološkom smislu, sama koncepcija Hrvata $i$ hrvatstva na razini pojedinca pluralna je i dvosmisleno definirana.
\end{abstract}

\section{Ključne riječi}

kulturni identitet, nacionalni identitet, nacionalizam, socijalna konstrukcija zbilje, intencionalnost svijesti, zaliha znanja, smisao, dualnost

\section{Uvod}

Zbilja svakodnevnoga života, zbilja je par excellence te se nameće iznad svih ostalih individualnih, odnosno subjektivnih izvedenica stvarnosti (Berger i Luckmann, 1992). Nadalje, prema Bergeru i Luckmannu (1992), pojedinac kognitivno stvara vlastitu zbilju u sklopu šireg društvenog konteksta. Subjektivna zbilja u pravilu se usklađuje sa zbiljom svakodnevnog života, što omogućava društveni život i uspostavu komponenata i granica svijeta života. Da bi zbilja svakodnevnoga života funkcionirala potrebna je stabilna zaliha znanja i standardizirani načini ponašanja, odnosno tipizacije, ${ }^{1}$ koje objektivizi-

Tipizacija se odnosi na pojam koji označava znanje u svijetu života. Drugim riječima, označava tipična obilježja predmeta ili osoba. Odnosi se na proces u kojemu se pojedinci prilagođavaju svijetu oko sebe (Abercrombie, Turner i Hill, 2008: 404). Tipizacije se formiraju kroz procese intrasubjektivnosti, odnosno objektivizacije kolektivne misli. 
raju stvarnost neovisno o pojedincu. Ipak, snaga pojedinca leži u stvaranju individualnih značenja i interpretacije određenih aspekata svijeta života. U ovome radu razmatra se individualna konstrukcija značenja odnosa nacionalnoga i kulturnoga identiteta. U tom smislu, osnovno analitičko sredstvo rada jest fenomenologija međuodnosa pojedinca i zalihe znanja koja mu je na raspolaganju. U radu se fenomenološki pristupa upravo zbog delikatnosti samog fenomena individualnih percepcija nacionalnog i kulturnog identiteta u hrvatskom društvu. Epistemološki potencijal fenomenologije jest taj da omogućava uvid kako u objektivne danosti svakodnevnog života, tako i u intencionalnost svijesti pojedinca prema tim danostima (u ovom slučaju intencionalnost svijesti pojedinca prema hrvatskom nacionalnom i kulturnom identitetu). Ovime se dobiva uvid u aktera kao neovisnog stvaratelja smisla onih komponenata stvarnosti koje su mu dane na raspolaganje. Pojedinac stvara neovisan osobni identitet na temeljima društvenih očekivanja.

U ovoj rečenici vidi se svojevrstan paradoks ostvarenja čovjeka u kontekstu društvenosti. Pojedinac je neovisan i slobodan odabrati, ali slobodan je odabrati samo varijante života ponuđene unutar kontekstualnih okvira određenog prostora. U tom smislu, osobom se ne rađamo, osobom postajemo (Mead, 2003: 131). ${ }^{2}$ Ova, moglo bi se reći egzistencijalistička, pretpostavka čovjeka nužno se nadovezuje na ontološku fenomenologiju Jean-Paula Sartrea, posebice po pitanju slobode. Slobodni smo propitkivati, uočavati. U svijet smo bačeni neodređeni od ikoga ili ičega, svijet je dan nama na raspolaganje, na ostvarenje smislenosti vlastitog života, ali cjelokupna razina slobode stvara prostor izrazite nesigurnosti (Sartre 1964). Na tom tragu, osnovne teze ovoga rada kreću se u smjeru razlaganja upravo te nesigurnosti pojedinca u pogledu višestrukosti objektivnih mogućnosti ostvarenja hrvatskoga nacionalnoga i kulturnoga identiteta.

Da bi takva analiza fenomenologije odnosa kulturnoga i nacionalnoga identiteta u hrvatskom društvu bila moguća, potrebno je razmotriti fenomenologiju u kontekstu njene upotrebe u sociološkog teoriji. Valja dakle, razriješiti nedoumice oko osnovnih pojmovnih alata fenomenologije koji će nam pomoći pri analizi postavljenih ciljeva. To su prije svega pojmovi zaliha znanja, tipizacija i intencionalnost svijesti. Nakon razrade teorijskih pretpostavki rada daje se uvid u odnos kulturnog i nacionalnog identiteta u hrvatskom društvu. Iz navedenoga slijedi fenomenološka interpretacija i analiza problematike današnje stvarnosti hrvatskoga društva. Također, bitno je naglasiti da rad polazi od pretpostavke dualnosti identiteta. Dualnost se najčešće formira u vidu dihotomije nominalno/virtualno, tj. vanjsko i unutarnje (Jenkins, 1996: 25). Kako bi pojedinac mogao funkcionirati u širem društvenom kontekstu, mora se prilagoditi simboličkim zahtjevima grupe/društva. Tako, iako pojedinac posjeduje »suverenitet « osobnog identiteta, mora ga koordinirati s objektiviziranom predodžbom kolektivnoga.

\section{Fenomenologija kao protosociologija}

Fenomenologija kao filozofska disciplina pretpostavlja bavljenje filozofijom kao strogom znanosti, orijentiranom na fenomene koje u svojoj osnovnoj biti karakterizira transcendentalna, subjektivna dimenzija. Jedna od idejnih osnivača fenomenologije, Edmund Husserl (2007), fenomenologiju je zamislio kao metodu kojom će se filozofija vratiti svijetu koji je izgubila (ili ispustila) iz domene svoje apstrakcije. U tom je kontekstu blizak i Karlu Marxu, koji smatra da se filozofija odmaknula od svijeta i postala nefilozofska disciplina 
koja svoju svrhu iskazuje po sebi bez ikakve refleksije na stvarnost (Marx, 1971 u Pavić, 2014: 34). ${ }^{3}$ Husserl razrješava problematiku filozofije kao znanosti putem novog smjera u obliku fenomenologije.

U Husserlovu proučavanju svakodnevnih pojava s filozofskog aspekta, objektivni fenomeni ili prirodne danosti ne mogu se spoznati u svojoj biti. One u našoj spoznajnoj dohvatnosti nisu ništa drugo doli individualne reprezentacije značenja i zbilje (Husserl, 1975). Objekt kao takav nemoguće je dohvatiti izvan subjektivnog dojma pojedinca. Drugim riječima, svijet života formira se kroz različite danosti $i$ interpretacije bitka (fenomena) te preko umnih opravdanja i osmišljavanja vlastitog izvoda takozvanog svijeta života (Enciklopedija, 2018). U tom smislu, valja raspraviti domet fenomenologije kao takve. Sam doseg objašnjen je pojmom intencionalnosti svijesti. Naime, svijet u određenoj esencijalnoj danosti nemoguće je spoznati (prirodna danost), ali ono što je moguće jest proučavati međuodnos svijesti pojedinca i fenomena na koji je ta ista svijest usmjerena. U tom pogledu, govorimo o intendiranju svijesti prema nekom objektu koji za svijest (pa i za svijet života) postaje zbiljski - u određenoj interpretaciji te iste zbilje. ${ }^{4}$

Kada je riječ o zalihi znanja, o njoj možemo govoriti kao o akumuliranoj »riznici« prethodnih iskustava svakodnevice koji nam pomažu u reguliranju i funkcionalnosti svakodnevne interakcije. U zalihu znanja u generalnom smislu ubrajamo sve elemente društvenoga života koji stvarnost formiraju u njenom objektivnom obliku. Ono znanje koje se nalazi u našoj zajedničkoj zalihi jest implicitno znanje, uzima se zdravorazumski i čini neupitni okvir svakog djelovanja (Dragojević, 1996: 90).

U osnovnom shvaćanju zalihe znanja, može se izvesti zaključak o jednakosti zalihe znanja i kulturnog identiteta određenoga društva, međutim, zaliha znanja svakako je širi pojam od kulturne identifikacije. Zaliha se znanja u odnosu prema kulturnom identitetu može predstaviti kao resurs, temelj izgradnje određenog tipa kolektivnoga identiteta. Naime, zaliha znanja proizvod je svih vrsta kolektivnog identiteta i upravo je ona u središtu ovoga rada s obzirom na specifičnu upotrebu zalihe znanja hrvatskoga društva u formiranju nacionalnoga i kulturnog identiteta. Fenomenološki gledano, zaliha znanja stvara objektivne resurse za pojedinca koji se koriste pri interakciji u ostvarenju pojedinca kao društvenoga bića (Berger i Luckmann, 1992).

Ovdje svakako valja postaviti pitanje etiologije kolektivne zalihe znanja. Etiologija zalihe znanja, ali i značenja historijski je vezana uz institucije koje su zadužene za administraciju i funkcionalnost tog znanja za svakodnevni život (s akterima) (Berger i Luckmann, 1995). Zaliha znanja stvorena je kroz interakcijske obrasce zajednice koji se ponavljaju u svojoj smislenosti. Takvom znanju iskazana je visoka razina povjerenja kako od strane cjelokupne zajed-

»Osoba je nešto što ima razvoj, ona ne postoji od početka, pri rođenju, nego nastaje u procesu društvenog iskustva i aktivnosti, dakle razvija se u danoj individui kao rezultat njenih odnosa spram tog procesa kao cjeline i spram drugih individua unutar tog procesa.« (Mead, 2003: 131)

U Marxovu bi se pogledu filozofija trebala usredotočiti na refleksivan odnos prema svijetu. Svijet je potrebno osloboditi od filozofije, a filozofiju od svoga svjetovnog obli- ka u obliku ideologije (Marx, 1971 u Pavić, 2014: 35).

4

Detaljniji pregled pojma intencionalnosti svijesti prikazao je Dan Zahavi (2011). Prema njegovu mišljenju, Husserlov pojam intencionalnosti svijesti može se promatrati kroz nekoliko ključnih kategorije. To su, prije svega, $a k t$, značenje, predmet intencije, signitivna danost, intuitivna danost, evidencija i kategorijalni zor. 
nice tako i od strane pojedinca. Ta zaliha znanja osigurava minimalne razine zajedničkog znanja (Berger i Luckmann, 1995: 20). koje se kasnije može (smije) interpretirati i pluralizirati unutar sebe samoga (ali nikada izvan).

Kao što je već naglašeno, značenje komponenata zalihe znanja određeno je intersubjektivno. Drugim riječima, pojedinac sam interpretira i hijerarhizira određene komponente znanja, ovisno o vrsti društvene prilagodbe koju želi ostvariti. Bilo bi pogrešno zatvoriti se u subjektivni determinizam djelovanja, a negirati utjecaje kolektiva i same zalihe znanja na konstrukciju značenja. Iako se stvara subjektivno značenje zalihe znanja, potrebno je istu sagledati u generalnom smislu. Naime, zaliha znanja podrazumijeva i tipizacije kolektivnih identiteta koje objektivno postoje za određeni društveni kontekst. Značenje tih identitetskih sastavnica može se hijerarhizirati ili filtrirati prema željama pojedinca, ali samo unutar pravila osnovnih komponenta znanja koja se preuzimaju. Pojedinac nije u mogućnosti u potpunosti izmijeniti pretpostavljene karakteristike znanja, već ih može individualno prilagoditi, slijedeći zadana pravila kolektiva. $\mathrm{U}$ tom smislu, identitet se u fenomenološki može shvatiti kao dijalektika između pojedinca i društva. Društveni odnosi održavaju, modificiraju ili čak preoblikuju određene forme identiteta, što će biti vidljivo u daljnjoj elaboraciji teme. Društva, naime, imaju povijest u čijem se toku pojavljuju identiteti, međutim, te povijesti sačinjavaju ljudi određenih identiteta (Berger i Luckmann, 1992: 201). Time se omogućava reprodukcija kolektivnog identiteta kroz akumulaciju zalihe znanja te kroz načine raspolaganja s istom. Kako bi, ipak, kolektivni identitet održavao smislenost, za svakog pojedinca potrebna je disperzija društvenih uloga i položaja, ali i razumijevanje i smislenost tog položaja. Iz tog razloga, kao potkrjepa zalihi znanja uozbiljuju se tipizacije (definicija u fusnoti prethodnog dijela). Pojedinac svoj odnos prema zalihi znanja određuje kroz tipične načine crpljenja iste za specifične situacije u kojima se nalazi. Tako se hrvatska zastava koristi u drugačijoj smislenosti (iako sličnoj) za vrijeme Svjetskog prvenstva u nogometu i za vrijeme svečanih mimohoda hrvatske vojske. Emocije su prisutne, ali u drugačijem kontekstu, u drugačijoj formi znanja i razumijevanja tih emocija - intencionalnost svijesti usmjerena je na drugačiji način.

Ovdje se približavamo osnovnim teorijskim polazištima rada koji se u većoj mjeri usmjeravaju prema upotrebi fenomenologije unutar sociološkog diskursa. Kako se fenomenologije veže prvenstveno uz filozofsku misao, sama implementacija fenomenoloških metoda spoznaje bila je, $s$ jedne strane, revolucionarna, a s druge strane, nailazila je na otpor. Najbolja predodžba spomenutog leži u analizi odnosa sociologa 70-tih godina 20. stoljeća prema korištenju fenomenologije u sociologiji, Edwarda G. Armstronga (1979), koji cjelokupnoj hiperkritici fenomenološke sociologije tog vremena daje slikovit naziv phenomenologophobia.

Možda za najprihvatljiviji kompromis (iako ne u potpunosti) valja uzeti onaj koji fenomenologijsku sociologiju shvaća kao protosociologiju. Fenomenologija kao protosociologija, koja je osnovno analitičko sredstvo ovoga rada, razvila se pod utjecajem Alfreda Schutza i njegovog implementiranja fenomenološke analize u sociološke teorije. Naime, Schutz fenomenologiju predstavlja unutar sociologije kroz uvažavanje određenih, objektivnih načela svijeta života. Na sociologiji svojstven način negira potpunu relativizaciju objektivnoga unutar svijeta života i postavlja kategoriju tipizacije (ranije spomenuto) kao skup formi unutar svakodnevnoga života koje postoje neovisno o subjektivnim interpretacijama istih (Wagner, ur., 1970). Ipak, baveći se fenomenologijom, kako navode Alfred Schutz i Thomas Luckmann (1973), ne 
bavimo se sociologijom u njenim apsolutnim granicama. U tom kontekstu govorimo o protosociologiji kao disciplini iznalaženja analitičkog sredstva kontekstualizacije fenomena kako bi eventualna, buduća empirija bila moguća. Mogućnosti bavljenja empirijom u tom smislu podilazi osnovnim konceptima fenomenologije. Upravo na tim osnovama Aspers (2009) definira 7 koraka pri implementaciji fenomenološke tehnike u empirijskim istraživanjima. ${ }^{5}$ Ono što je u fenomenološkom istraživanju najbitnije jest upravo ovaj konstrukt drugoga reda koji istraživača postavlja u ulogu interpretatora socijalne zbilje određenog konteksta. Taj konstrukt drugoga reda, kako bi zadržao i osigurao znanstvenu validnost $\mathrm{u}$ bitnom ovisi o prethodno definiranom teorijskom konceptu i pojmovnoj razradi fenomena (Aspers, 2009; 6). Tek kada je takva vrsta analize uključena, može se krenuti u razradu konstrukata prvog reda, te kasnije drugog. U ovom radu razrađuje se ta teorijska okosnica empirije fenomenologije odnosa nacionalnog i kulturnog identiteta da bi se osigurala znanstvena validnost interpretacije $\mathrm{u}$ vidu konstrukta drugog reda.

Kompleksnost ovoga rada, koja je ujedno i glavna poteškoća, jest pluralnost dvosmjerne dualnosti fenomena i komponenata stvarnosti koje se proučavaju. Dualnost osobnog i kolektivnog identiteta (unutarnjeg i vanjskog), dualnost individualnog i kolektivnog značenja, dualnost nacionalnog i kulturnog identiteta imaju zajedničku karakteristiku uzajamnog djelovanja unutar dualnog modela. Osobni identitet djeluje na kolektivni identitet i obratno. Individualno značenje sudjeluje u formiranju kolektivnog značenja, ali kolektivno značenje stvara temelje samog poimanja stvarnosti. Kulturni identitet dinamičko je svojstvo nacionalnoga identiteta, koji pak regulira načine reprodukcije kulturnog identiteta (Grbić, 1994: 29). Svakako je bitno imati na umu spomenutu dvosmjernost pri elaboraciji fenomenološkog modela odnosa kulturnog i nacionalnog identiteta u hrvatskom društvu. U toj dvosmjernosti individualno/kolektivno neizostavno je spomenuti osnovne koncepte sociologije znanja u njenim idejnim i teorijskim začecima. Prije svega, to se odnosi na rad Karla Mannheima (2007) koji uz uvažavanje individualnih snaga pri formiranju odnosa prema svijetu uključuje i takozvanu uvjetovanost znanja bitkom. Ta uvjetovanost proizlazi iz strukturalnih osnova koje organiziraju praktična znanja svakodnevice kako bi pojedincu olakšala snalaženje. U tom smislu, radi se distinkcija između proučavanja ideologije i proučavanja koje sociologija znanja poduzima. Sociologija znanja ne bavi se intencionalnim iskrivljenjima znanja koje se može očitati samo kroz uviđaj ideologije onog drugog. Ona (sociologija znanja) bavi se svime što u određenom kontekstu spada u znanje. Sve kolektivne smjernice koje su latentno internalizirane i legitimizirane od strane pojedinaca bez posebnih interesa određenih skupina/ klasa/generacija ljudi (Mannheim, 2007: 284-295). Na ovim osnovama gleda se i na fenomenologiju odnosa nacionalnog i kulturnog identiteta. Naime, nasuprot uvriježenim stavovima o nacionalnosti kao ideološkoj, ${ }^{6}$ u ovome radu istoj se pristupa sa strane individualne percepcije nacionalnog identiteta i stvaranja latentne smislenosti za svakodnevni život. Neupitan je manipula-

Svaka fenomenološka studija u empirijskom izričaju trebala bi podrazumijevati sedam međusobno prožetih koraka: određivanje istraživačkog problema, orijentacijska istraživanja, odabir teorijskog koncepta, proučavanje konstrukta prvog reda, konstrukcija konstrukta drugog reda, potraga za nepredviđenim efektima studije, usporedba s dosadašnjim istraživanjima tematike (Aspers, 2009: 5).
6

Prema Kordić (2010), na nacionalne identitete na prostorima bivše Jugoslavije poziva se najčešće kada se žele opravdati važni politički zahtjevi. U tom procesu ističe se različitost spram drugih nacija i njihovih kultura. 
cijski potencijal nacionalizma, međutim, analiza istoga u tom pogledu izlazi iz paradigmatskih dohvata i fokusa ovoga rada. Ono što se pak može proučiti jest to kako se distinkcija u spoznavanju nacionalnog identiteta kroz kulturnu zalihu znanja odražava na svakodnevnu interakciju. Drugim riječima, kako dvije osobe u interakciji s (u kolektivnom smislu) istim nacionalnim identitetom, ali drugačijim kulturološkim (socijalizacijskim) osnovama za formaciju tog identiteta mogu pronaći zajednički jezik. Tko je već Hrvat?

\section{Odnos kulturnoga i nacionalnoga identiteta}

U razmatranju odnosa kulturnoga i nacionalnoga identiteta, bitno je napomenuti nekoherentnost promišljanja o međusobnom prožimanju nacionalnoga i kulturnoga. Draškić Vićanović (2014) navodi kako se odnos kulturnog i nacionalnog identiteta može protumačiti kroz međusobnu ontološku povezanost. Naime, kulturni se identitet formira njegovanjem određene kulture, samim time i tradicije te razvijanjem pojedinih komponenata ljudske kulture (npr. mit, jezik, religija), a kultura se manifestira kroz određene principe nacije (Draškić Vićanović, 2014: 48).

Iako spomenuta analiza podupire prethodno spomenutu dvosmjernu dualnost fenomena nacionalnog i kulturnog identiteta, situacija odnosa dviju identitetskih sastavnica znatno je kompleksnija u pogledu hrvatskoga društva, tj. hrvatskog nacionalnog i kulturnog identiteta. U kontekstu hrvatskoga društva, vidljiva je kohezija nacionalnog i etničkog identiteta, koja se intenzivira sve do određenja etnonacionalizma. ${ }^{7}$ Iako je etnonacionalizam proces koji nije u potpunosti zahvatio hrvatsko društvo, odnos etničkog i nacionalnog identiteta konkretizira međusobni odnos prema kulturi i kulturnom identitetu.

U ovome radu kreće se od tradicionalne pretpostavke međusobnog prožimanja etničkog i kulturnog identiteta. Naime, klasična sociologija etničnosti kreće od procesa detekcije kulturnih elemenata (npr. jezik, religija, običaji) koji determiniraju kulturni identitet (Sekulić, 2007; 357). S druge pak strane, razlike u odnosu etničkog i kulturnog identiteta mogu se uočiti u tome što etnički identitet (ali i nacionalni?) podrazumijevaju društvenu strukturu združenu na osnovi određene vrste povezanosti, dok je kulturni identitet vezan striktno uz tradiciju, tj. akumulirano kolektivno iskustvo (Grbić, 1994: 29). Nadalje, Grbić ističe kako gubljenje pojedinih elemenata kulture ne znači gubitak izvornog etničkog identiteta. Cjelovitost kulturnog identiteta osiguravaju politički, ekonomski, društveni, psihološki i drugi mehanizmi koji usmjeravaju kulturno u odnosu na potrebe trenutnog etničkog identiteta. Etnos, a samim time i etnički identitet, nisu determinirane kulturne kategorije, već su povijesni proizvod specifičnih društvenih interakcija (Supek, 1989: 148). Etnički identitet u koheziji s nacionalnim dobiva političku dimenziju koja selektivno određuje dominantne sastavnice kulturnih resursa. Kroz spomenute procese formiraju se zalihe znanja podupirane institucijama koje omogućavaju osobnu identifikaciju. Hrvatsko društvo kao relativno homogeno (DZS, 2011) svoju nacionalnu identifikaciju ostvaruje kroz simboličke vrijednosti povezane uz etnički identitet. Nacionalni identitet u tom je kontekstu politička manifestacija etničkog identiteta. Ipak, u konkretnijem slučaju analiza odnosa etničkog, kulturnog i nacionalnog identiteta zbog preciznosti se ne govori o etničkom nacionalizmu već se koristi pojam integralnog nacionalizma. Integralni nacionalizam u slučaju Republike Hrvatske precizniji je termin upravo zbog sinteze kontinuiteta hrvatskoga državnog prava i etničkog nacionalizma (Sekulić, 2001: 158). 
Kako se etnički identitet ostvaruje kroz nacionalni? Prema Mežnarić (1989), kolektivni interesi koji grupu ili etniju dovode najbliže naciji jesu sloboda udruživanja i posebna, ustavom osigurana prava kulturne autonomije i jezika. Ipak, iako navedeno tvori osnovu razmatranja etničke grupe kao nacije, etnička grupa postaje nacijom tek kada se u model uvede posjedovanje političke suverenosti (Mežnarić, 1989). Samim time, potkrjepljuje se tvrdnja o naciji kao svojevrsnoj političkoj tvorevini etničkoga identiteta. Ovdje je neizostavno spomenuti znanstveni doprinos Dunje Rihtman-Auguštin koja u svojim analizama razmatra odnos političkih rituala i kulture, tj. upravo taj odnos kulturnog i nacionalnog. Ovakav tip analize za ciljeve našega rada valja promatrati kroz svojevrsnu etiologiju međuodnosa kulturnog i nacionalnog u hrvatskom društvu. Istraživanja Rihtman-Auguštin etnološke su naravi te kao takva pružaju funkcionalnu potkrjepu za nastavak fenomenologije odnosa nacionalnog i kulturnog identiteta. Rihtman-Auguštin (1992) analizira upotrebu političkih rituala u konstrukciji zaliha znanja određenih vremenskih epoha hrvatske stvarnosti. Naglašava važnost kontrole prostora i vremena te uspoređuje načine na koje se ista vršila u doba socijalizma te u začecima Republike Hrvatske kao neovisne i suverene države. Prostor i vrijeme kao i kompletna zaliha znanja socijalističke vlasti fokusirala se na jačanje jugoslavenskih simbola i rituala te je kao takva negirala nacionalne identitete. Početkom 90-ih godina, nacionalni identiteti jačaju te se na političkom planu može reći kako ne uspijeva ni jedna politika koja se ne oslanja na nacionalni osjećaj (Rihtman-Auguštin, 1992: 40).

U samoj toj formulaciji neupitna je moć i sposobnost politike u definiranju komponenata zalihe znanja koje tvore kulturni identitet u hrvatskom društvu. Ipak, dominacija nacionalnog identiteta nije jednostrana. Uzevši u obzir dinamično svojstvo kulturnog identiteta, svakako je potrebno uključiti pojedinca kao sudionika interakcije i sustvaratelja kulturnih praksi unutar određene zajednice.

Pojedinac kao sustvaratelj kulturnog identiteta te njegovatelj nacionalnog identiteta interpretira odnos ovih dviju identitetskih sastavnica na temelju vlastite smislenosti ili smislenosti vlastitog svijeta života. ${ }^{9} \mathrm{U}$ tom smislu u medijskom prostoru često se spominje svojevrsna diskrepancija korištenja zalihe znanja poznatija pod nazivom polarizacija hrvatskoga društva. Iako se na prvi pogled čini prvenstveno makro-strukturalni problem, ono je etiološki mikro-strukturalan proces. S tom pretpostavkom, valja razmotriti ovu diskrepanciju ili polarizaciju kroz alat fenomenološke analize u vidu pojedinčeva odnosa prema kulturnom i nacionalnom identitetu. Kroz elaboraciju i detaljan opis ovih fenomena na mikro razinama daje se konkretan uvid u društvenu podijeljenost hrvatskoga društva.

Etnonacionalizam označava proces okupljanja na osnovi etničke pripadnosti od strane nove elite $\mathrm{u}$ polietničkim društvima koja stvara djelotvoran oblik kolektivne akcije za postizanje ciljeva. Ovim procesom etnički identitet predstavlja novu konstrukciju. U toj konstrukciji ljudi vide priliku za povećanjem društvenoga ugleda, imovinske koristi ili političkog dobitka (Katunarić, 1994: 210).

Prema Državnom zavodu za statistiku, u popisu stanovništva 2011. godine upisano je 90,42 \% etničkih Hrvata.
Svijet života u ovom slučaju predstavlja mikro- i mezo-zajednicu u kojoj pojedinac aktivno sudjeluje te kroz koju stvara vlastite stavove i značenja zalihe znanja. Kao primjere može se navesti obitelj, prijatelji, poslovno okruženje. 


\section{Fenomenologija kao epistemološka metoda razmatranja odnosa kulturnoga i nacionalnoga identiteta u hrvatskom društvu}

Kao što je spomenuto, etiologija odnosa kulturnoga i nacionalnoga identiteta u ovom radu započinje analizom mikro-strukture, tj. odnosom akcije i značenja u stvaranju društvene zbilje određene zajednice. Kako bi fenomenološki obuhvatili ovaj odnos, bitno je shvatiti internalizaciju, tj. subjektivizaciju kolektivnog identiteta u hrvatskom društvu. U tom smislu, razmatramo pojedinčevu upotrebu zalihe znanja u formiranju odnosa (značenja), prema kulturnom, a zatim i nacionalnom identitetu. Važno je napomenuti kako se upotreba zalihe znanja kod pojedinca ne odnosi hijerarhijski prema komponentama kulturnog i nacionalnog. I kulturni i nacionalni identitet $\mathrm{u}$ hrvatskom društvu vezani su uz zalihu znanja i tvorbu kolektivne, par excellence zbilje. Kao što je ranije navedeno (Grbić, 1994), kulturni identitet veže se uz tradiciju i subjektivizaciju vrijednosti i normi određenog društva, dok se nacionalni identitet veže uz simbolički dio zalihe znanja. Simbolički dio zalihe znanja stvara kolektivnost kroz semiotičko određivanje nacionalnih simbola (Rihtman-Auguštin, 1992). Drugim riječima, nacionalni identitet u pravilu je socijalno konventan i samim time apstraktna je kategorija. Ovom elaboracijom daje se naslutiti, tj. iznijeti teza kako nacionalni identitet stvara snažniju kolektivnu povezanost, nego što to radi kulturni. Potkrjepu ove tvrdnje možemo naći u stupnju isključivosti, tj. distinkciji mi - oni koja je u nacionalnom identitetu izraženija nego li je to slučaj s kulturnim identitetom. Nacionalni identitet podrazumijeva korištenje i simbola koji, s jedne strane, vrše upravo spomenutu distinkciju mi - oni, a s druge strane, koriste se kao faktor uspostave osjećaja solidarnosti i zajedništva članova društva koji internaliziraju određeni nacionalni identitet i popratne simbole.

»Multivokalnost simbola i neodređenost njihova značenja omogućuje uspješnost u izvršavanju njihove temeljne političke uloge razvijanja osjećaja zajedništva i kolektiva (...).« (Trako Poljak, 2016; 32-33)

Međutim, na području svijeta života, resursi koji se koriste iz zalihe znanja određenoga društva (u ovom slučaju hrvatskoga društva) ne izvlače se niti se definiraju istoznačno pri individualnom formiranju nacionalnoga i kulturnoga identiteta. To znači da se pri definiranju osobne interpretacije nacionalnoga i kulturnoga identiteta koriste različiti resursi iz zajedničke zalihe znanja pojedinoga društva. Svako korištenje zalihe znanja i svaka takozvana rutinizacija svakodnevice pomaže nam da »zaboravimo « lomljivi karakter svijeta života (Dragojević, 1996: 90). Tom procesu doprinosi kako kulturni, tako i nacionalni identitet.

Pri fenomenološkom određivanju odnosa nacionalnoga i kulturnoga valja naglasiti njihovu genetičku različitost. Naime, kulturni identitet jest forma koja se razvija iz postojeće zalihe znanja, međutim, ona je u svojim osnovama dinamična. Iako kulturni identitet, i sastavnice određene kulture postoje ovisno o zalihi znanja koja je pretpostavljena određenom društvu, one su ovisne i o interakcijskim procesima, odnosno o svijetu života. Taj svijet života odrediv je u svojoj neodredivosti do mjere u kojoj se služi rutiniziranim formama zalihe znanja. Drugim riječima, kultura svoju genezu crpi iz zalihe znanja, ali se kroz svijet života, kroz interakciju formira u stabilne kulturno identitetske obrasce. Takozvani kulturni identifikatori svoju stabilnost iznalaze u rutiniziranoj funkcionalnosti. Unatoč stabilnosti, kulturni identitet nije kruta forma, stoga je »otporniji« od ostalih vrsta kolektivne identifikacije. Kulturni 
identitet u ovoj analizi predstavlja se kao proizvod odnosa zalihe znanja i svijeta života.

Nacionalni identitet, s druge strane, formira se kao apstraktna dimenzija zalihe znanja. Temeljen na simboličkim prezentacijama kolektivne pripadnosti, nacionalni identitet karakterizira krutost te slaba prilagodljivosti dinamičnom svojstvu kulture. Ipak, iako relativno kruta kategorija, nacionalni identitet također je podložan manipulaciji svijeta života i to od strane kategorije moći unutar svakodnevne interakcije. Ta moć svoj legitimitet crpi iz političke sfere djelovanja kao legitimne unutar određenoga društva. Kao što je ranije navedeno, etnički identitet političkom intervencijom može prijeći u nacionalni identitet (Sekulić, 2001), što uvelike mijenja odnos spram kulturnoga. Dok je odnos etničkoga i kulturnoga identiteta funkcionalno dinamičan, odnos kulturnoga i nacionalnoga identiteta hijerarhijski je određen u korist nacionalnoga. To znači da stabilnost nacionalnoga identiteta definira i odabire kulturne sastavnice koje koristi u ispunjavanju vlastite simboličke samobitnosti. U tom kontekstu možemo gledati nacionalizaciju tradicije u korist stvaranja »mi« pripadnosti.

Načini korištenja kulturnog identiteta u određenom društvu dijelom ovisi o načinima reprezentacije nacionalnog identiteta, njegovoj stabilnosti, te načinima na koje nacionalne komponente odabiru za sebe važne dijelove zalihe znanja. Na ovaj način stvara se tipizacija kulturnog identiteta s funkcijom legitimacije nacionalnoga.

U fenomenološkom kontekstu, nacionalni identitet, ili pak nacionalni identiteti u Republici Hrvatskoj, tvore zalihe znanja kojima se pojedinac koristi u svakodnevnom životu. Ipak, zaliha znanja nije određena kroz potpunu neovisnost aktera. Akter se rađa u vrijednosnom sklopu, kako svoje obitelji tako i šire zajednice. Primarna socijalizacija određuje prvu formu njegove zalihe znanja. Sekundarna socijalizacija ili učvršćuje primarna znanja ili je konfliktna prema sastavnicama istog. Sve to vodi k pojedinčevoj internalizaciji kolektivne zalihe znanja ili bar sastavnica tog znanja koji odgovaraju pojedinčevom iskustvu i načinu života (Berger i Luckmann, 1992). U tom bi smislu nacionalni, ali i kulturni identitet bio faktor integracije, on/oni moraju biti strukturalno jednoznačno definirani. Ako pak ta jednoznačnost izostane svijet života, individualna reinterpretacija zalihe znanja, takve kolektivne identitete konfuzno tumači.

Nadovezujući se na to, valja spomenuti kako se u hrvatskom medijskom prostoru sve intenzivnije piše i govori o takozvanoj polarizaciji društva. Iako se gotovo nikada ne objašnjava značenje tog izraza, nepobitno je postojanje određenih različitosti unutar hrvatske kulture, politike, ekonomije i društva. Podijeljenost društvene zbilje nikako ne doprinosi dinamici svijeta života. Prije nego što se upustimo u elaboraciju hrvatske zbilje valja se ograditi od generalizirajućih pretpostavki stavova. Ono što se fenomenološkom analizom postiže jest sagledavanje fenomena u njegovom značenjskom izvodu. Naime, društvena distinkcija u Republici Hrvatskoj očita je komponenta svijeta života, međutim taj svijet života karakterizira specifična situacija historijske manipulacije zalihom znanja kako bi se stvorile tipizacije i smjernice za stvaranje i prihvaćanje kolektivnog identiteta. Pretpostavljene varijacije zalihe znanja međusobno pobijaju određene komponente suprotne strane. Historijskim kontinuitetom one su stvorile međusobno odvojenu percepciju hrvatskoga kulturnoga i nacionalnoga identiteta. U polariziranom društvu značenje kulturnoga i nacionalnoga nije jednoznačno. Primjer za spomenuto može se pronaći u svakodnevnoj medijskoj prezentaciji takozvane ljevice i desnice. 
Individualno značenje pripadnosti ljevici ili desnici može varirati u svome intenzitetu, ali jedan je faktor stalno prisutan, a to je faktor odvajanja vlastitih stavova od onoga drugoga (Hrvatstvo ljevice nije korelat Hrvatstva desnice).

Pri samom kraju valja odgovoriti na sljedeće pitanje: na koje načine pojedinac »pliva« u svijetu života konstruiranom na ovim osnovama? Pri samoj primarnoj socijalizaciji. dijete od svojih roditelja preuzima već situiranu percepciju o hrvatskoj stvarnosti. Drugim riječima, od rane mladosti uči se kulturna i nacionalna distinkcija hrvatskoga društva. Distinkcija nije direktno preuzeta, već se ući jedan dio zalihe znanja koji je predodređen za jednu varijantu iskazivanja hrvatskoga i kulturnoga identiteta. Svaki komentar signifikantne osobe, svaki medijski prenesen konflikt stvara percepciju te diskrepancije vrijednosti kao društveno prihvatljive. U analizi fenomena odnosa nacionalnoga i kulturnoga identiteta društveni konflikt i atmosfera linča usadila se u samu zalihu znanja. To su ujedno kategorije koje se bez iznimke koriste sa svih strana sustava društvene zbilje kada se ne zadovolji osnovni vrijednosni stav koji određena osoba ili grupa zagovara.

\section{Zaključak}

Cilj ovoga rada bilo je analizirati fenomenologiju nacionalnoga i kulturnoga identiteta u hrvatskom društvu. Odnos ovih kolektivnih formi identiteta karakterizira šira slika dualnosti kolektivnog i individualnog značenja društvenoga života. Da bi se uspješno obuhvatila oba fenomena i prikazala osnova njihove povezanosti potrebno je razlučiti načine ostvarenja zalihe znanja i tipizacija u svijetu života specifičnom za hrvatsko društvo. U tom smislu kroz složeni historijski kontinuitet stvaranja identitetskih sastavnica, kulturni identitet povezuje se s nacionalnim, što naposljetku određuje percepciju pojedinca o zbilji svakodnevnoga života. Stvara se kohezija individualnog i kolektivnog, ali samo u jednoj od kolektivno ostvarenih (u kulturnom smislu) varijanti. Interakcija s drugačijim formama kulturnog i nacionalnog identiteta, tj. s pojedincima koji prakticiraju drugačiji tip zalihe znanja koja određuje nacionalni identitet, obilježena je konfliktom i predrasudama. Iako ovaj konflikt podupiru ideološki, kolektivni faktori, ona se ostvaruje prvenstveno na mikrorazini, odnosno ovakav tip odnosa nacionalnog i kulturnog identiteta ostvaruje se odozdo prema gore. Drugim riječima, pojedinci svojim akcijama usmjerenima kroz dobivenu zalihu znanja legitimiraju i iznova ostvaruju već spomenutu polarizaciju. Upravo zbog spomenute analize, trenutna podjela hrvatskog društva ne može se okarakterizirati kao prvenstveno ideološkom služeći se terminologijom sociologije znanja. Svakodnevna iskustva distinkcije nacionalnog i kulturnog u hrvatskom društvu ne određuje lažna svijest ili pak partikularni interesi, već korištenje te distinkcije da bi pojedinci opravdali smisao svojeg vlastitog života unutar određenog kolektiva - korištenjem zalihe znanja. Ta zaliha znanja po pitanju formacije nacionalnog identiteta od samog svojeg početka prožeta je vrijednosnim konfliktima. Tipovi nacionalnih identifikacija u Hrvatskoj temelje se na distanciranju od drugog. Isto tako, svaka varijanta značenja nacionalnoga identiteta koristi zalihu znanja na drugačije načine, stvarajući poseban odnos prema hrvatskom kulturnom identitetu. Hrvatski kulturni identitet žrtva je povijesne podijeljenosti poimanja nacionalnoga identiteta u kojoj se kultura koristi kao legitimacija vlastite strane nacionalne varijante identiteta. $U$ epistemološki razrađenom razmatranju fenomena daje se uvid u odnos identitetskih sastavnica u zbilji svakodnevnoga života. Kao takva, fenomenološka analiza pokazuje se kao vrijedno analitičko 
sredstvo za pripremu detaljnije elaboracije u vidu empirijskog istraživanja. Ta empirija u duhu fenomenološke tradicije (unutar sociologije, ali i filozofije) svakako bi zahtijevala odmak od klasičnih percepcija znanstvenog istraživanja koje ograničava spoznaju društvene svakodnevice na kvantitativnu analizu podataka (Latour, 2005). U tom smislu, kvalitativna metodologija u vidu dubinskih intervjua, posebice po pitanju teme ovoga rada, nameće se kao nužnost, posebice ako se u obzir uzmu pretpostavke fenomenološkog istraživanja (Aspers, 2009). Otkrivanjem značenja koje pojedinac pridaje nacionalnom i kulturnom identitetu mogu se pronaći upravo one sastavnice kolektivnog identiteta (pounutrenih u svijesti pojedinca) koje doprinose već spomenutim distinkcijama.

\section{Literatura}

Abercrombie, N.; Hill, S.; Turner, B. (2008): Rječnik sociologije, prevoditelji Jadranka Čačić-Kumpes i dr., Jesenski i Turk, Zagreb.

Armstrong, E. G. (1979): »Phenomenologophobia«, Human Studies 2 (1979) 1, str. 63-75, doi: https://doi.org/10.1007/bf02127216.

Aspers, P. (2009): »Empirical Phenomenology: A Qualitative Research Approach (The Cologne Seminars)«, Indo-Pacific Journal of Phenomenology 9 (2009) 2, str. 1-12, doi: https://doi.org/10.1080/20797222.2009.11433992.

Berger, P. L.; Luckmann, T. (1992): Socijalna konstrukcija zbilje, preveo Srđan Dvornik, Naprijed, Zagreb.

Berger, P.; Luckmann, T. (1995): Modernity, Pluralism and the Crisis of Meaning: The Orientation of Modern Man, Bertelsmann Foundation Pubs, Washington.

Dragojević, R. (1996): »Životnosvjetovni krajolik 'dobro-obaviještenog' Alfreda Schütza«, Revija za sociologiju 27 (1996) 1-2, str. 85-96.

Draškić Vicanović, I. (2014): »Kulturni identitet, nacionalni identitet i problem ukusa«, Arhe 11 (2014) 22, str. 47-56.

Državni zavod za statistiku (2011): Popis stanovništva 2011. godine. Dostupno na: https:// www.dzs.hr/ (pristupljeno 10. 2. 2018.).

Grbić, J. (1994): »Identitet, jezik i razvoj. Istraživanje o povezanosti etniciteta i jezika na primjeru hrvatske nacionalne manjine u Mađarskoj - 1. dio«, Narodna umjetnost 31 (1994) 1, str. 9-137.

Husserl, E. (2007): Ideje za čistu fenomenologiju i fenomenologijsku filozofiju, preveo Željko Pavić, Naklada Breza, Zagreb.

Husserl, E. (1975): »Neki spis«, u: Damjanović, M. (ur.), Fenomenologija, preveli Novakov, S. et al., Nolit, Beograd.

Jenkins, R. (1996): Social Identity, Routledge, London.

Katunarić, V. (1994): »Moć i etnonacionalizam«, Migracijske i etničke teme 10 (1994) 3-4, str. 209-224.

Kordić, S. (2010): »Ideologija nacionalnog identiteta i nacionalne kulture«, u: Ajdačić, D.; Lazarević Di Đakomo, P.; Jacobsen, P. (ur.), U čast Pera Jakobsena: zbornik radova, SlovoSlavia, Beograd, str. 225-239.

Latour, B. (2005): Reassembling the Social - An Introduction to Actor-Network-Theory, Oxford University Press, New York.

Mannheim, K. (2007): Ideologija i utopija, preveo Kiril Miladinov, Jesenski i Turk, Zagreb.

Mead, G. H. (2003): Um, osoba i društvo - sa stajališta socijalnog biheviorista, preveo Srđan Dvornik, Jesenski i Turk, Zagreb. 
Mežnarić, S. (1987): »Jedno moguće sociološko promišljanje o naciji i etnicitetu«, Migracijske i etničke teme 3 (1987) 2, str. 131-138.

Pavić, Ž. (2014): »Marxova rana kritika religije«, Studia lexicographica 8 (2014) 2, str. 33-53.

Rihtman-Auguštin, D. (1992): »O konstrukciji tradicije u naše dane: rituali, simboli i konotacije vremena«, Narodna umjetnost 29 (1992) 1, str. 25-42.

Sartre, J.-P. (1964): Egzistencijalizam je humanizam, preveo Vanja Sutlić, Veselin Masleša, Sarajevo.

Schutz, A.; Luckmann, T. (1973): The Structures of the Life-World: Volume 1, Northwestern University Press, Evanston.

Sekulić, D. (2001): »Je li nacionalizam hrvatska sudbina?«, Revija za sociologiju 32 (2001) 3-4, str. 157-174.

Sekulić, D. (2007): »Etničnost kao društvena konstrukcija«, Migracijske i etničke teme 23 (2007) 4, str. 347-372.

Supek, O. (1989): »Etnos i kultura«, Migracijske i etničke teme 5 (1989) 2-3, str. 145-153.

Trako Poljak, T. (2016): Hrvatski simbolički identitet - Značenje nacionalnih simbola iz perspektive hrvatskih građana, TIM Press, Zagreb 2016.

Wagner, H. R. (ur., 1970): Alfred Schutz on Phenomenology and Social Relations, University of Chicago Press, Chicago.

Zahavi, D. (2011): Husserlova fenomenologija, preveo Nebojša Mudri, AGM, Zagreb.

\title{
Erik Brezovec
}

\section{Phenomenology of the Relation between} National and Cultural Identity in Croatian Society

\begin{abstract}
This paper aims to analyse the phenomenology of the interdependence of national and cultural identity in Croatian society and present how the empowerment of national and cultural identity in the Croatian society generates an individual expression of being Croatian. To be able to speak about this process, it is essential to define the relationship between cultural and national identity in the Republic of Croatia. A duality of influence characterises this relationship. Cultural identity is an essential element of the construction of a national, which determines the direction of cultural dynamics. The phenomenological level of theoretical analysis of the mentioned phenomenon places the internalisation of the identity constituents into the focus. As consciousness is always intentional, or intent on an object, it is necessary to study the ways of understanding the building of an individual's identity throughout the collectively provided stocks of knowledge. Such type of construction or internalisation of collective assumptions presupposes the relative independence of the actors in the construction of their reality. Relative independence as a term stems from the inability to separate the action from the structural frameworks on issues of identity. An individual is free to form the meaning, but that meaning is created within a particular context and frame. This context inherently creates the essence of available knowledge. The basic problem with the knowledge of national and cultural identity (in the broader sense of the culture) is that this knowledge is enabled in two dominant polar variants. An individual constructs his identity through a variety of knowledge supply, dominant (or accessible) through his life. Such a process of realising a person dispels a national identity. In the phenomenological sense, the very conception of Croats and being Croatian at the individual level is plural and ambiguous.
\end{abstract}

\section{Key words}

cultural identity, national identity, nationalism, social construction of reality, intentional consciousness, knowledge stock, meaning, duality 